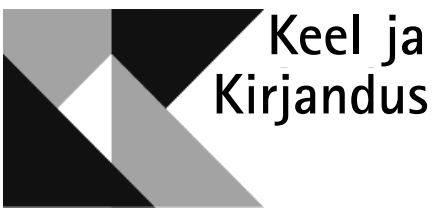

\title{
EESTI ÕPILASTE KEELEHOIAKUD 2011. AASTAL
}

\author{
ANNI TAMMEMÄGI, MARTIN EHALA
}

A astal 2003 viisid Martin Ehala ja Katrin Niglas kooliõpilaste seas läbi esindusliku uuringu, mille eesmärk oli saada ülevaade hoiakutest, mis võiksid mõjutada noorte keele-eelistusi olukordades ja keskkondades, kus on võimalik valida eesti ja inglise keele vahel, näiteks veebisuhtluses, meelelahutust tarbides, koolis ja ülikoolis, tööelus ning segaperekonnas (vt Ehala, Niglas 2004). Valimisse arvatud 1887 ópilase vastustest ilmnes, et noored küll väärtustavad oma emakeelt identiteedi osana, kuid on samal ajal üsna skeptilised eesti keele kui vahendi tulevikuperspektiivide suhtes (Ehala, Niglas 2004: 2139). Seega võib öelda, et eesti keelel oli 2003. aastal õpilaste silmis üsna tugev integratiivne väärtus, sama ei saa aga öelda selle instrumentaalse väärtuse kohta.

Uuringust möödunud kaheksa aasta jooksul on maailmas ja Eestis aset leidnud mitmesuguseid olulisi muutusi. Euroopa Liiduga ühinemine on teinud vaba liikumise Euroopas iseenesestmõistetavuseks. Õpilaste ja üliõpilaste vahetusprogrammid on reaalsus, välismaal õppimine ja töötamine pole hüpoteetiline võimalus, vaid tõsiselt võetav alternatiiv kohalikele võimalustele. Füüsilise liikumisvabaduse suurenemisest ehk olulisemgi on aga interneti lai levik, mis on muutnud ingliskeelse info- ja suhtlusruumi ka kõige kaugema maanurga noorte igapäevaelu osaks. Sage inglise keele kasutamine muudab selle koduseks ja käepäraseks, tiheda ja laiaulatusliku läbikäimise kaudu ühtlustuvad hoiakud ja väärtused. Teisest küljest on maailm viimaste aastate jooksul muutunud ka märgatavalt ärevamaks, sagenenud on etnilised konfliktid, ilmnenud immigrantide lõimimise probleemid. Peaaegu kõikjal 
Euroopas on pilvitu multikulturalism asendunud tunduvalt kriitilisema suhtumisega etnilistesse ja kultuurilistesse vähemustesse, tugevnenud on rahvuslikud meeleolud. Sama võib täheldada ka Eestis.

Saamaks teada, millist mõju on avaldanud need muutused hoiakutele eesti keele suhtes, korraldasime sama metoodika alusel uue uuringu, mis leiab käesolevas artiklis kajastamist võrdlevalt varasemaga. Esmalt tutvustame lähtekohti, peatudes uuringu meetodil, valimi koostamise põhimõtetel ja andmeanalüüsi meetoditel. Seejärel on vaatluse all tulemused, millest lähtuvalt teeme järeldusi õpilaste praegustest keelehoiakutest ja nende dünaamikast pärast eelmist uuringut.

\section{Uuringu meetod}

Hoiakute uurimisel on sotsiaalpsühholoogias aukartustäratav ajalugu (vt nt Krosnick jt 2005), ka keelehoiakuid on uuritud palju ja mitmekülgselt (vt Garrett jt 2003; Garrett 2010). Kasutusel on palju erinevaid meetodeid, mida võib laias laastus jagada kaheks: otsesteks ja kaudseteks. Otsesed meetodid lähtuvad uurimisel peamiselt intervjuudest ja küsimustikest. Kaudsed meetodid kasutavad mitmesuguseid eksperimente, kus uuringu otsene eesmärk on varjatud, et vähendada tundlike teemade puhul poliitilise korrektsuse mõju. Keelehoiakute uurimisel on kaudsetest meetoditest levinuim võrdsete maskide test (vt Lambert jt 1960). Selle puhul loeb üks ja sama inimene lindile ühe ja sama teksti, kuid teeb seda erinevate aktsentidega. Katseisikute ülesanne on nende tekstikatkete põhjal hinnata kõneleja isikuomadusi, järeldusi tehakse aga hoopis selle põhjal, missugused on hindaja hoiakud vastava aktsendiga seotud sotsiaalse või etnilise rühma kohta. Kaudseid meetodeid esindavad ka testid, kus mõõdetakse reaktsiooni kiirust mõiste ja hinnangu vahelise seose tuvastamisel (nt Greenwald jt 2002). Kaudsete meetodite plussiks on nende võime avada tundlikes valdkondades autentsemaid keelehoiakuid. Otsesed meetodid sobivad seal, kus pole karta, et katseisikute hinnangud on ühiskondliku surve tõttu kallutatud. Nende eeliseks on kaudsete meetoditega võrreldes see, et nad võimaldavad koguda detailsemat infot hoiakutest ühe nähtuse erinevate tahkude kohta, samal ajal kui kaudsed meetodid annavad vaid üldpildi.

Kuigi eesti keele väärtustamine on eesti ühiskonnas üsna tundlik teema, ei ole see vast sedavõrd ideologiseeritud, et noored võiksid anonüümse (veebipõhise) küsimustiku puhul oma vastuseid korrektsemaks kohendada, kui nad seda just alateadlikult enesepettuseks ei tee. Seetõttu pole tugevat põhjust kaudsete meetodite eelistamiseks, lisaks on keele puhul vajalik saada infot niihästi integratiivsete kui ka instrumentaalsete hoiakute kohta, mida on kergem uurida otseste meetoditega. Just seetõttu kasutati Martin Ehala ja Katrin Niglase 2003. aasta uuringus otsest meetodit: 44 küsimusest koosnevat kirjalikku ankeeti (Ehala, Niglas 2004). Sama küsimustik võeti aluseks ka siin vaadeldavas uuringus. Tehtud on vaid mõningad muudatused: seoses euro kasutuselevõtuga on ühes küsimuses kroonide mainimisest loobutud ja arvulise väärtuse asemel nimetatud suurusjärk. Integratsiooniameti kaotamisega seoses tuli ümber sõnastada küsimus, kus seda asutust mainiti. Kaalumist tekitas ka mõnes küsimuses esinev sõna muulased, mida on hakatud vii- 
mastel aastatel vähem kasutama. Siiski pole mitte-eestlane parem, venelane aga on osalt laiema, osalt kitsama tähendusega. Lisaks võiks sellise olulise määratluse asendamine vastuseid mõjutada. Seetõttu jäi küsimustikku algupärane muulased alles ning näib, et küsitluses osalenud on nimetatud sõna ka üheselt mõistnud. Uuringu tulemused näitavad, et vene noored on valmimad muulastega lähedasemaid suhteid looma, avaldades tõenäoliselt niiviisi poolehoidu oma rahvusrühmale.

Ankeedis esitatud küsimused liigituvad temaatiliselt nelja rühma: inglise keele kasutamine igapäevaelus, valmisolek eestikeelse keelekeskkonna säilitamiseks, valmisolek eestikeelse hariduskeskkonna säilitamiseks, valmisolek muulaste keeleliseks integratsiooniks. Lisaks 44 põhiküsimusele sisaldab ankeet ka sotsiodemograafilist tausta puudutavaid küsimusi: vastaja vanus, sugu, emakeel, kooli tüüp (linnakool, maakool), klass, klassi tüüp (tavaklass, reaalklass, humanitaarklass, inglise keele kallakuga klass, muu), elukoht (maakond), perekonna sissetulek (keskmisest parem, keskmine, keskmisest halvem), vanemate haridus (mõlemal kõrgem, ühel kõrgem, mõlemal kesk(eri)haridus, muu) ja vanemate rahvus (mõlemad eestlased, ema eestlane, isa eestlane, mõlemad muust rahvusest).

\section{Valimi koostamise põhimõtted}

Teismeiga on etnilise identiteedi kujunemise ja kinnistumise periood (Phinney 1990: 510; French jt 2006: 2). Et noored on etnilise identiteedi otsingutes kultuurilistele ja keelelistele mõjudele väga avatud, siis on keele jätkusuutlikkuse jaoks oluline roll just noortel (De Bot, Stoessel 2002: 6). Suuresti sõltub nende identiteediotsingute tulemustest keele põlvkondlik edasikandumine. Täiskasvanuna tuleb neil langetada otsus, millises keelekeskkonnas nad kasvatavad oma järeltulijaid, ja see sõltub muude mõjukate tegurite kõrval ka nende etnilise identiteedi tugevusest. See on peamine põhjus, miks uuring keskendub just õpilaste keelehoiakutele.

Andmete kogumise viisiks on kombineeritud valikuskeemid. Eeldades, et piirkondlik ja sooline aspekt on peamised keelehoiakute varieeruvust mõjutavad tegurid, on uuringus kihtideks maakonnad ja klastriteks koolid. Soolise esindatuse tagab see, et Eesti koolidele on iseloomulikud segaklassid. Uuringus osalesid 10. ja 12. klassi opilased.

Küsitlus toimus 2011. aastal veebruarist aprillini. Uuringus osales 732 koolinoort üle Eesti. Ankeete oli võimalik täita nii elektrooniliselt kui ka paberkandjal. Interneti vahendusel täitis küsitluse 228 õpilast, paberil 504 . Küsitluse täitmise viis tulemusi ei mõjutanud.

Uuringus osales 10. ja 12. klassi õpilasi peaaegu võrdselt, vastavalt 48,2 ja $51,8 \%$. Noormehi oli $43,3 \%$ ja neide $56,7 \%$. Et osalemine sõltus koolide nõusolekust, siis ei õnnestunud saavutada Eesti kohta esinduslikku valimit: Tallinn on mõnevõrra alaesindatud ning Lääne-Virumaa ja Saaremaa tugevalt alaesindatud (vt tabel 1). Linnakoolide õpilasi oli vastanutest 79,8\%, mis on tunduvalt enam kui maakoolide õpilasi. Osalenud koolide seas oli ka üks eliitkool, mille õpilaste arv moodustab üldisest vastanute arvust 8,5\% (62). Klassi tüübiks märkis $32,1 \%$ tavaklassi ja sama suur protsent vastanuist reaalklassi, $18 \%$ humanitaarklassi, 5,7 \% (42) bioloogia-keemiaklassi, 4,6 \% (34) kunstiklassi, 4,1\% (30) spordiklassi, 2,2\% (16) inglise keele kallakuga 
Valimi suurus maakondade lõikes

\begin{tabular}{|l|r|l|}
\hline Maakond & Arv & \% \\
\hline Tartumaa & 137 & 18,7 \\
Harjumaa & 116 & 15,8 \\
Jõgevamaa & 68 & 9,3 \\
Raplamaa & 68 & 9,3 \\
Põlvamaa & 63 & 8,6 \\
Viljandimaa & 59 & 8,1 \\
Võrumaa & 56 & 7,7 \\
Valgamaa & 47 & 6,4 \\
Hiiumaa & 33 & 4,5 \\
Ida-Virumaa & 29 & 4 \\
Pärnumaa & 24 & 3,3 \\
Läänemaa & 16 & 2 \\
Järvamaa & 13 & 1,8 \\
Saaremaa & 2 & 0,3 \\
Lääne-Virumaa & 1 & 0,1 \\
Kokku & $\mathbf{7 3 2}$ & \\
\hline
\end{tabular}

klassi ja 1,1 \% (8) meediaklassi. Kuigi valim ei ole esinduslik, on see siiski piisavalt suur, et anda ligilähedane ettekujutus eesti kooliõpilaste 2011. aasta keelehoiakutest.

Ankeet sisaldas küsimusi ka perekondliku tausta kohta. Keskmisest paremaks pidas oma perekonna sissetulekuid 19,7\% vastanuist, keskmisest halvemaks $10,5 \%$. Kõige enam, 69,8 \%, oli aga neid, kes pidasid oma vanemate majanduslikku olukorda keskmiseks. Mõlemad vanemad olid kõrgharidusega 21,9 \%-l vastanuist, ühel vanemal oli kõrgharidus 37,3 \%-l. Kesk(eri)haridusega vanemaid oli 37,9 \%. Muu hariduse märkis 2,9 \% (21) vastajaist. Suuremal osal vastajaist olid mõlemad vanemad eestlased, sellise vastuse andis $91,4 \%$ osalenuist. 6,7 \%-l (48) oli üks vanemaist eestlane. Mõlemad vanemad märkis muust rahvusest olevaks 1,9\% (14). Eesti keelt pidas oma emakeeleks $98,8 \%$, vene keelt 1,2\% (9) vastanuist.

Siinkohal on oluline mainida, et kui Martin Ehala ja Katrin Niglase 2003. aasta uuringus jäeti venekeelsete õpilaste vastused välja, sest need erinesid märgatavalt eesti noorte arvamustest, siis käesoleval juhul on vene emakeelega noorte hinnangud valimisse alles jäetud. Seda mitmel põhjusel. Üldiselt ei eristu need eesti keelt emakeelena kõnelevate õpilaste vastustest. Üksikutel juhtudel vene noorte arvamus küll lahkneb, kuid erinevused pole märkimisväärselt suured. Sellegipoolest on artiklis mõningad statistiliselt olulised seisukohtade vahed välja toodud. 


\section{Tulemused}

Uuringus kasutatud ankeedi 44 küsimust jagunevad sisulistesse rühmadesse. Küsimuste rühmitamisel on lähtutud M. Ehala ja K. Niglase artiklist (2004), mille aluseks olevas uuringus kasutati selleks faktoranalüüsi. Selle tulemusel jagunesid küsimused 11 rühma (faktorisse). Et kordusuuringu üks keskseid eesmärke oli võrrelda 2011. aasta tulemusi varasema uuringuga, on rühmad moodustatud samadest küsimustest. Järgnevalt vaadeldaksegi andmeanalüüsi tulemusi 11 faktorist lähtuvalt. Kirjeldatud on sotsiodemograafiliste tegurite seost õpilaste keelehoiakutega, lisaks on vaadeldud ka erinevate keelehoiakute omavahelisi seoseid. Ülevaatlikkuse huvides on võrdlevalt esitatud nii varasema kui ka uuema uuringu tulemused. Andmete esitamisel toome esmalt ära rühma kuuluvad küsimused ja seejärel tabeli vormis vastuste jaotumise rühma kohta tervikuna.

\section{Inglise keele kasutamine igapäevaelus}

\subsection{Inglise keele kasutamise intensiivsus}

1) Kas Te räägite oma sõpradega omavahel inglise keelt?

2) Kas Teil on tundeid (üllatust, armastust, viha jm) kergem väljendada inglise keeles?

3) Kas Te mõtlete inglise keeles?

4) Kas Te kasutate inglise keelt internetis (jututoas, e-mailides)?

$\begin{array}{llllll}\text { Aasta } & \text { Alati } & \text { Sageli } & \text { Mõnikord } & \text { Harva } & \text { Mitte kunagi } \\ 2011 & 4 \% & 20 \% & 33 \% & 30 \% & 13 \% \\ 2003 & 3 \% & 15 \% & 29 \% & 33 \% & 21 \%\end{array}$

Üksikküsimuste vastuseid pole ei siin ega teistes tabelites eraldi välja toodud, sest on kasutatud faktoranalüüsi. See tähendab, et faktoritesse ehk rühmadesse koondatud üksikküsimused mõõdavad kõik üht ja sama nähtust, käitumismustrit: esimese faktori puhul inglise keele kasutamise intensiivsust, teise puhul inglise keele pragmaatilisusest lähtuvat kasutamist jne.

Vastustest näeme, et 2011. aastal korraldatud küsitluse andmeil kasutab $24 \%$ osalenuist iga päev aktiivselt inglise keelt. Need andmed muutuvad eriti kõnekaks, kui mõelda, et see tähendab tervelt neljandikku kõigist küsitluses osalenuist. Soolisest aspektist vaadatuna kasutavad poisid inglise keelt rohkem kui tüdrukud. Enam tarvitavad inglise keelt kõrgharidusega vanemate lapsed. Inglise keele kasutamise intensiivsuse juures on oluline roll ka küsitluses osalenud õpilaste vanemate rahvusel. Inglise keele kasutamine on omasem neile õpilastele, kellel on mõlemad vanemad eestlased või üks vanemaist eestlane. Eliitkooli õpilased suhtlevad inglise keeles igapäevaselt enam kui tavakoolide oppilased. Statistiliselt on viimase puhul tegemist keskmise efektiga.

Võrdlusest nähtub, et inglise keele kasutamise intensiivsus on suurenenud, mille põhjal võib väita, et ka inglise keele oskus on paranenud. Seesugune tendents on põhjendatav ingliskeelsete maade prestiiži jätkuva kasvu ja sellest tuleneva kultuurilise mõjuvõimu laienemisega. On tähelepanuväärne, 
et tunduvalt vähem on varasemaga võrreldes neid, kes inglise keelt mitte kunagi ei kasuta. Nende arv moodustab 2011. aasta küsitletutest vaid $13 \%$. Niisiis haarab inglise keel Eesti noorte seas üha kindlamat positsiooni.

\section{Valmisolek eestikeelse keelekeskkonna säilitamiseks}

Inglise keele kasutamise intensiivsust kajastavaid protsente vaadeldes võib väita, et 2011. aasta uuringu järgi valdab mingil tasemel inglise keelt vähemalt $87 \%$ küsitletuist. See tähendab, et neil on võimalus valida eesti keele ja inglise keele vahel. Ning sellega seoses ka kahe erineva kultuuriruumi vahel. Järgnevad neli faktorit kajastavad õpilaste valmisolekut eestikeelse keelekeskkonna säilitamiseks.

\subsection{Inglise keele kasutamine pragmaatilistel kaalutlustel}

1) Kas oleksite nõus eestikeelsetest subtiitritest filmi all loobuma, kui see muudaks kinopileti veerandi võrra odavamaks?

2) Kas ostaksite ingliskeelse menüüga mobiiltelefoni, kui see maksaks $5 \%$ vähem kui sama telefon eestikeelse menüüga?

$\begin{array}{llllc}\text { Aasta } & \text { Kindlasti } & \text { Pigem jah } & \text { Pigem ei } & \text { Kindlasti mitte } \\ 2011 & 34 \% & 29 \% & 29 \% & 8 \% \\ 2003 & 27 \% & 27 \% & 31 \% & 14 \%\end{array}$

Teades, et $87 \%$ uuemas küsitluses osalenuist valdab mingilgi määral inglise keelt, ei ole üllatav, et $63 \%$ oleks materiaalsetest kaalutlustest lähtuvalt nõus eestikeelsetest teenustest loobuma. Ka statistilisel analüüsil ilmneb, et inglise keele kasutamise intensiivsuse ja pragmaatiliste kaalutluste vahel on keskmine positiivne seos. Mõneti enam on eesti keelest loobumiseks valmis meessoost vastajad. See tendents on kooskõlas ka poiste aktiivsema inglise keele kasutamisega. Haritumate vanemate lapsed on pragmaatilisemad ja nõus eesti keelest inglise keele kasuks loobuma, kui see tähendab kokkuhoidu. Keelevalikul on mõjutavaks teguriks ka perekonna sissetulek. Võiks arvata, et kehvemal järjel olevad õpilased on raha säästmise eesmärgil valmimad keelevahetuseks kui jõukatest peredest pärit õpilased. Ometi ilmneb vastupidine tendents. Samuti võib öelda, et eliitkooli õpilased on keeleküsimuses pragmaatilisemad kui tavakoolide õpilased. Eliitkooli õpilaste utilitaarsuse põhjuseks ei ole tõenäoliselt materiaalsete võimaluste piiratus, sest küsitluses osalenud eliitkooli õpilased on tavakooli õpilastega võrreldes majanduslikult kindlustatumad. Pigem on põhjuseks nende igapäevane tavakooli õpilastest suurem inglise keele kasutamise intensiivsus ja -oskus. Niisiis on pragmaatilisemad poisid, haritumate ja jõukamal järjel vanemate lapsed ning eliitkooli õpilased.

Kõrvutades varasemaid ja hilisemaid tulemusi, võime siingi täheldada inglise keele kasutamise aktiivsuse tõusu, sest pragmaatikast lähtuv eesti keele vahetamine inglise keele vastu sellele kõhklematult viitab. Tendents on mõistetav: kui inglise keele oskus pealetungiva ingliskeelse kultuuriruumi mõjul kasvab, siis suureneb ka õpilaste võimalus kahe keele vahel valida. Ja nagu tabelist nähtub, on rahaline kokkuhoid suure hulga õpilaste jaoks pii- 
sav põhjus inglise keele eelistamiseks. Sotsiodemograafiliselt on kahes uuringus sarnaselt pragmaatilisemad meessoost vastajad, haritumate ja jõukamate vanemate lapsed.

\subsection{Inglise keel töökeelena firmas}

1) Kui Teile kuuluv eestlastest töötajatega väike edukas firma suhtleks põhiliselt suurte mõjukate välisklientidega, kas kehtestaksite firmasiseseks töökeeleks inglise keele?

2) Kui teate, et Teie firma välismaalasest omanik on lubanud Teile lähemal ajal helistada, kas vastaksite oma töötelefonile igaks juhuks inglise keeles?

3) Kui Teie tulevasel töökohal ülemused nõuavad Teilt ingliskeelset aruandlust, kas nõuaksite ingliskeelseid aruandeid ka oma alluvatelt?

$\begin{array}{lllll}\text { Aasta } & \text { Kindlasti } & \text { Pigem jah } & \text { Pigem ei } & \text { Kindlasti mitte } \\ 2011 & 9 \% & 36 \% & 45 \% & 10 \% \\ 2003 & 8 \% & 24 \% & 46 \% & 21 \%\end{array}$

2011. aasta uuringus osalejaist eelistaks $45 \%$ välismaiste klientide ja ettevõtetega suheldes kasutada inglise keelt. Ingliskeelset eestimaist töökeskkonda aktsepteerivad enam Valgamaa noored, Pärnumaa õpilased on selles küsimuses aga kõige eestimeelsemad. Eesti emakeelega õpilased hindavad aga eestikeelset töökeskkonda rohkem kui vene emakeelega osalenud. Klasside lõikes on selles küsimuses eestimeelsemad 12. klassi õpilased.

$\mathrm{Ka}$ selle faktori puhul on märgata inglise keele eelistamise kasvu. Üsna võrdselt on neid õpilasi, kes kindlasti eestikeelsest töökeskkonnast loobuksid, kuid sellele vastukaaluks leidub uuema uuringu põhjal vähem neid, kes kindlasti eesti keelt eelistaksid. Erinevalt 2003. aasta uuringust ei näita uuem uuring, et maakoolide õpilased ingliskeelse töökeskkonna eelistajatena eristuvad. 2011. aastal kogutud andmete põhjal ei erine linna- ja maanoorte arvamused kuigivõrd. Samuti ei mängi rolli perekonna majanduslik olukord.

\subsection{Eesti keel töökeelena välisfirma Eesti esinduses}

1) Kas välisfirma Eesti esinduse välismaalasest tippjuht peaks oskama eesti keelt?

2) Kas välisfirma Eesti esinduses peaks töökeeleks olema eesti keel?

$\begin{array}{lllll}\text { Aasta } & \text { Kindlasti } & \text { Pigem jah } & \text { Pigem ei } & \text { Kindlasti mitte } \\ 2011 & 21 \% & 53 \% & 24 \% & 2 \% \\ 2003 & 28 \% & 47 \% & 20 \% & 5 \%\end{array}$

Kui umbes pool vastanuist näeb end eestimaise ingliskeelse töökeskkonnaga kohanevat, siis sama oodatakse Eestis tegutsevatelt välisfirmadelt. Nimelt märgib tervelt $74 \%$ õpilastest, et välismaised ettevõtted peaksid üldiselt eesti keelt tööelus rakendama. Nii arvatakse soost, klassist, emakeelest ja teistest sotsiodemograafilistest näitajatest sõltumata.

Kuigi õpilaste protsent, kes välisfirma Eesti esinduses töökeelena kindlasti või pigem eesti keelt näevad, pole oluliselt muutunud, on vähenenud nen- 
de osatähtsus, kes kindlasti eesti keelt pooldavad. Erinevalt 2003. aasta uuringust ei paista silma venekeelsete noorte mõnevõrra eitavam suhtumine.

\subsection{Vabatahtlik keelehoid}

1) Kui otsitaks vabatahtlikke, kes ühiskondlikult kasuliku töö korras jagaksid laiali eesti keele infovoldikuid, kas osaleksite vabatahtlikuna?

2) Kas oleksite nõus tegema iga nädal tund aega ühiskondlikult kasulik$\mathrm{ku}$ tööd, olles muulasest eakaaslasele eesti keele vestluspartneriks?

3) Kui keeleamet kutsuks üles teatama keeleseaduse rikkumisjuhtudest, kas Te jälgiksite enda ümbrust ja teataksite?

$\begin{array}{lllll}\text { Aasta } & \text { Kindlasti } & \text { Pigem jah } & \text { Pigem ei } & \text { Kindlasti mitte } \\ 2011 & 11 \% & 36 \% & 41 \% & 12 \% \\ 2003 & 12 \% & 31 \% & 42 \% & 15 \%\end{array}$

Keelehoiu küsimuses jagunevad õpilaste arvamused peaaegu pooleks. Enam on selleks valmis naissoost vastajad. Sugu on keelehoiuküsimuses keskmise efektiga mõjur. Kõrgemalt haritud vanemate lapsed on aga keelehoiu suhtes negatiivsemalt meelestatud, nii ka eliitkooli õpilased.

Suurt muutust selles küsimuses kahe uuringu vahel toimunud pole. Ometi on täheldatav positiivne tendents: uuemas uuringus osalenud on varasemaga võrreldes valmimad keelehoiuteemadega tegelema. Ka leiab 2011. uuringus kinnitust, et tüdrukud ja vähem haritud vanemate lapsed oleksid keele säilitamisega tegelemisest rohkem huvitatud.

\section{Valmisolek eestikeelse hariduskeskkonna säilitamiseks}

Toimiva eestikeelse töökeskkonna eelduseks on sellele eelnev eestikeelse hariduse omandamine. Ingliskeelse hariduse eelistamine eestikeelsele pärsib aga omakeelse haridussüsteemi arengut. Järgnevad kolm faktorit vaatlevad õpilaste valmisolekut ka edaspidi hariduskeelena eesti keelt aktsepteerida.

\subsection{Ingliskeelse hariduse kättesaadavus Eestis}

1) Kas Eestis peaks olema võimalus soovi korral omandada kõrgharidus inglise keeles?

2) Kas Eesti riik peaks finantseerima eestikeelse keskhariduse kõrval ka ingliskeelset keskharidust?

3) Kas Eesti riik peaks finantseerima eestikeelse kõrghariduse kõrval ka ingliskeelset kõrgharidust?

4) Kas Eestis peaks olema võimalus soovi korral õppida ingliskeelses gümnaasiumis?

$\begin{array}{lllll}\text { Aasta } & \text { Kindlasti } & \text { Pigem jah } & \text { Pigem ei } & \text { Kindlasti mitte } \\ 2011 & 22 \% & 50 \% & 24 \% & 4 \% \\ 2003 & 30 \% & 43 \% & 21 \% & 5 \%\end{array}$


Tervelt $72 \%$ vastanuist peab ingliskeelset õpet Eestis vajalikuks ning pooldab ka selle riigipoolset finantseerimist. Ingliskeelse hariduse kättesaadavuse suurendamist pooldavad seejuures just eliitkooli õpilased. Üldiselt on õpilasi, kes soovivad ingliskeelse hariduse kättesaadavuse suurendamist, mõlemas uuringus võrdselt. Vähenenud on aga nende arv, kes seda kindlasti pooldavad. Juurde on tulnud aga nii-öelda kõhklejaid, kellel pole selles küsimuses kindlat seisukohta. Kui 2003. aasta uuringus sõltus ingliskeelse hariduse väärtustamine perekonna sissetulekust ja vanemate haridusest, siis nüüd see rolli ei mängi.

\subsection{Keeleõppe mahu suurendamine}

1) Kas eesti keele tunde peaks koolis rohkem olema?

2) Kas inglise keele tunde peaks koolis rohkem olema?

$\begin{array}{lllll}\text { Aasta } & \text { Kindlasti } & \text { Pigem jah } & \text { Pigem ei } & \text { Kindlasti mitte } \\ 2011 & 9 \% & 38 \% & 46 \% & 7 \% \\ 2003 & 12 \% & 40 \% & 40 \% & 8 \%\end{array}$

$47 \%$ vastanuist pooldab keeleõppe mahu suurendamist. Keeletundide lisamist peavad vajalikuks naissoost vastajad ja eliitkooli õpilased. Keeleõppemahu suurendamise suhtes on negatiivsemalt meelestatud 10. klasside õpilased. Eelmise faktori tulemuste valguses pole üllatav, et soovitakse just inglise keele tundide arvu kasvu.

Kuigi 2011. aasta uuringu põhjal eelistatakse pigem inglise keele kui eesti keele tundide arvu tõstmist, on õpilaste soov keeleõppe mahtu suurendada varasemaga võrreldes siiski veidi langenud. Võimalik, et inglise keele õppimise vastu on huvi varasemast väiksem sel põhjusel, et arvatakse end olevat võimelised seda erinevate meediumite vahendusel ka ise õppima. Arvestades inglise keele laia haaret, ei pruugi see seisukoht ekslik ollagi. Eesti keele õppimise huvi kadumist võib põhjendada aga huvi tõusuga ingliskeelse kultuuriruumi vastu üldiselt. Viimane ilmneb ka mitme teise faktori puhul. Niisiis ei saa sarnaselt varasemale uuringule väita, et kes tahab keeleõppe mahu suurendamist, soovib nii eesti kui ka inglise keele tundide arvu tõstmist. Sarnasus on aga see, et keeleõppe mahu suurendamist pooldavad eelkõige neiud ja vanemate klasside õpilased.

\subsection{Ingliskeelse hariduse tähtsus}

1) Kas paneksite oma lapse ingliskeelsesse kooli, kui see oleks sama hea tasemega ja kodule sama lähedal kui eestikeelne kool?

2) Kas paneksite oma lapse ingliskeelsesse lasteaiarühma?

3) Kas Teie laps peaks kõrghariduse omandama välismaal?

$\begin{array}{lllll}\text { Aasta } & \text { Kindlasti } & \text { Pigem jah } & \text { Pigem ei } & \text { Kindlasti mitte } \\ 2011 & 10 \% & 31 \% & 48 \% & 11 \% \\ 2003 & 12 \% & 32 \% & 41 \% & 15 \%\end{array}$


Selle faktori eesmärk on välja selgitada, kuidas planeerivad vastajad oma laste tulevikku, millise hariduskeele kasuks nad otsustaksid. $41 \%$ peab ingliskeelset haridust oluliseks. Kui ka tulevikus otsustab nii palju õpilasi inglise keele kasuks, eelistades seda nii alus- kui ka kõrghariduse tasandil, on Eesti haridussüsteemi jätkusuutlikkus küsimärgi all. Mõneti enam tähtsustavad ingliskeelset haridust vene emakeelega noored, 10. klassi, eliitkooli õpilased ja suurema sissetulekuga perede lapsed.

Nagu ingliskeelse hariduse kättesaadavamaks muutmise küsimuses on vähenenud nende arv, kes seda kindlasti pooldavad, on ingliskeelse hariduse tähtsustamisegi puhul märgatav väikene langus. Samal ajal on varasemast vähem neid, kes sellele kindlalt ei ütlevad. Seega on veidi tõusnud nende õpilaste arv, kes kumbagi äärmusse ei kuulu ning on pigem äraootaval seisukohal. Sarnaselt varasemale rõhutavad ingliskeelse hariduse tähtsust inglise keele süvaõppega ja jõukamatest peredest noored.

\section{Valmisolek muulaste keeleliseks integratsiooniks}

Peale inglise keelt puudutavate hoiakute väljaselgitamise oli uuringu üks eesmärke vaadelda ka õpilaste muulastesse suhtumist. Järgnevad faktorid sellele teemale keskenduvadki.

\subsection{Etniline avatus}

1) Kas tunneksite rõõmu ja uhkust, kui mõni muulasest Eesti sportlane võidaks olümpiamedali?

2) Kas muulaste ülemäärast integreerimist tuleks vältida, sest see hävitab eesti keele omapära?

$\begin{array}{lllll}\text { Aasta } & \text { Kindlasti } & \text { Pigem jah } & \text { Pigem ei } & \text { Kindlasti mitte } \\ 2011 & 29 \% & 47 \% & 20 \% & 4 \% \\ 2003 & 30 \% & 41 \% & 22 \% & 6 \%\end{array}$

Selle faktori puhul on muulaste ülemäärast integreerimist puudutavale küsimusele antavaid vastuseid faktoranalüüsil pööratud nii, et kindlasti väljendab suuremat etnilist avatust. Suur osa vastanuist on etniliselt avatud, olles valmis muulasi eesti keele- ja kultuurikeskkonda integreerima. Mõnevõrra silmatorkav on $20 \%$ vastanute ebalev suhtumine, kuid seda neutraliseerib madal etniliselt täiesti suletute protsent. Muulaste suhtes on tolerantsemad naissoost õpilased ja tavakoolide noored ning 12. klassi õpilased.

Kuigi valmisolek teisi rahvusi aktsepteerida oli ka varemalt suur, nähtub tabelist, et etniline avatus on veelgi kasvanud. Kui varem oli etniliselt avatud $71 \%$ vastanutest, siis lubab selle näitaja kasv $76 \%$-le ennustada jätkuvat tõusutrendi. Sotsiodemograafiliste näitajate lõikes pole selles küsimuses aga sarnasusi võimalik välja tuua.

\subsection{Muulastega lähedane suhtlemine}

1) Kas Teid häiriks, kui Teie õde või vend armuks mõnda kohalikku muulasesse? 
2) Kas Teid häiriks, kui olude sunnil peaksite ülikoolis ühiselamutuba jagama muulasega?

3) Kas Te parema meelega väldiksite kohalike muulastega suhtlemist?

4) Kas võtaksite kutse vastu, kui Teie muulasest naaber Teid külla kutsuks?

5) Kas halva keeleoskusega eesti keelt rääkiv muulane häbistab eesti keelt?

$\begin{array}{lllll}\text { Aasta } & \text { Kindlasti } & \text { Pigem jah } & \text { Pigem ei } & \text { Kindlasti mitte } \\ 2011 & 3 \% & 11 \% & 45 \% & 41 \% \\ 2003 & 3 \% & 8 \% & 34 \% & 55 \%\end{array}$

Siin väljendavad suuremat tolerantsust vastusevariandid pigem ei ja kindlasti mitte, välja arvatud neljandas küsimuses, mille skaala on keskmise arvutamiseks pööratud. Eelmise faktoriga sarnaselt ollakse valmis muulastega lähedasi suhteid looma: tervelt $86 \%$ peab igapäevast muulastega suhtlemist vastuvõetavaks. Soosivamad on selles osas küll siingi tüdrukud, kusjuures sool on muulastega tiheda läbikäimise osas keskmine efekt. Eliitkooliga võrreldes on suhtlemisaltimad tavakoolide õpilased.

Kuigi endiselt on üsna suur hulk õpilasi nõus muulastega lähedasi suhteid looma, näitab tabel üldises plaanis siiski väikest langust. Silmatorkavalt suur on aga nende õpilaste arvu langus, kes on lähedaste kontaktide loomisest kindlasti huvitatud. Sellist nihet on raske teisiti seletada kui pärast 2007. aasta pronkssõduri kriisi tekkinud suurema võõristusega venelaste suhtes. Kuid nii nagu varasemaski uuringus on soosivamad tüdrukud.

\subsection{Eesti keele kasutamine segaperekonnas}

1) Kui Teie tulevane abikaasa või elukaaslane ei oleks rahvuselt eestlane, kas ta peaks selgeks õppima eesti keele?

2) Kui Teie tulevane abikaasa või elukaaslane ei oleks rahvuselt eestlane, kas peaksite oluliseks õpetada oma lapsele eesti keelt?

3) Kui Teie tulevane abikaasa või elukaaslane ei oleks rahvuselt eestlane, kas Teie perekonna igapäevane suhtluskeel peaks olema eesti keel?

$\begin{array}{lllll}\text { Aasta } & \text { Kindlasti } & \text { Pigem jah } & \text { Pigem ei } & \text { Kindlasti mitte } \\ 2011 & 36 \% & 46 \% & 15 \% & 3 \% \\ 2003 & 44 \% & 42 \% & 11 \% & 3 \%\end{array}$

Selles küsimuses domineerivad valimis protsentuaalselt need õpilased, kes eesti keele valdamist segaperekonnas oluliseks peavad. Need noored moodustavad $82 \%$ vastanuist. Taas kord paistavad eesti keelele kindlaks jäämisega silma naissoost küsitletud. Venekeelsete vanematega ja vene keelt emakeelena kõnelevad noored kasutaksid segaperekonnas eesti keelt vähem. Kuigi üldiselt võib ennustada, et segaperes jäädakse eesti keele kasutamisele kindlaks, ilmneb siiski väike langus. Sellegipoolest on ühtviisi madalaks jäänud nende arv, kes eesti keelest kindlasti loobuksid. 


\section{Faktoritevahelised seosed}

Sotsiodemograafiliste mõjude kõrval on oluline kirjeldada ka faktorite omavahelisi seoseid. Selleks on kasutatud korrelatsioonianalüüsi. Järgnevalt on ära märgitud need küsimusterühmad, mille vahel esineb nõrk, keskmine või tugev seos. Olgu öeldud, et tugevalt seotud alarühmi on vaid üks.

Inglise keele kasutamise intensiivsuse ja pragmaatikast lähtuva keelevaliku vahel on keskmine positiivne korrelatsioon $(r=0,44)$, mis tähendab, et kui ollakse aktiivsed inglise keele kasutajad, ollakse nõus ka inglise keele kasuks otsustama, kui see on majanduslikult kasulik. Nõrk positiivne korrelatsioon $(r=0,2)$ on inglise keele kasutamise intensiivsuse ja ingliskeelse töökeskkonna eelistamise vahel. Nii ei ole imekspandav, et nõrk positiivne vastastikune seos esineb ka inglise keele kasutamise ja ingliskeelse hariduskeskkonna tähtsustamise vahel ( $r=0,21)$, sellega seoses oodatakse ka riigipoolset finantseerimist $(r=0,26)$. Ilmneb $\mathrm{ka}$, et mida paremini inglise keelt vallatakse, seda ebatõenäolisem on, et vastajad kasutaksid eesti keelt segaperekonnas. Selles osas valitseb faktorite vahel nõrk negatiivne seos $(r=-0,18)$.

Ôpilased, kes on igapäevastes juhuslikes valikutes nõus utilitaarsetel kaalutlustel eesti keelest inglise keele kasuks loobuma, aktsepteeriksid ka töökeelena inglise keelt. Tegemist on nõrga positiivse korrelatsiooniga $(r=0,2)$, millest nähtub, et episoodilised pragmaatilised valikud ennustavad sarnaseid valikuid tööelus: kui olukord seda nõuab või kaasnevad inglise keele eelistamisega mingid hüved, ollakse valmis ka töökeskkonnas eesti keelest loobuma. Ja et ingliskeelsesse tööellu võimalikult lihtne sulanduda oleks, peavad praktilise mõtlemisega õpilased vajalikuks ka ingliskeelse hariduse kättesaadavuse suurendamist. Sellele viitab nõrk positiivne korrelatsioon $(r=0,24)$.

Kui ühest küljest iseloomustab utilitaarseid õpilasi soov keelevaliku abil raha säästa, siis teisest küljest tähendab see ka energia ja ajaressursi kokkuhoidu. Nimelt valitseb nõrk negatiivne korrelatsioon $(\mathrm{r}=-0,16)$ pragmaatilisuse ja eesti keele segaperekonnas kasutamise vahel: mida praktilisemad ollakse, seda vähem püütakse segaperes eesti keelt tarvitada. Samal ajal on kasust lähtuvad vastajad altimad muulastega lähedasi suhteid looma, sellele viitab nõrk positiivne korrelatsioon $(r=0,12)$.

Eraldi tasub väljatoomist ka haridus- ja töökeele valikusse puutuv. Seotud on ingliskeelse hariduse tähtsustamine ja inglise keele kui firmasisese töökeele kasutamine. Esineb keskmine positiivne korrelatsioon $(r=0,4)$. Samal ajal ei poolda ingliskeelse hariduse tähtsustajad välisfirma Eesti esinduse töökeelena inglise keelt. Esineb nõrk negatiivne korrelatsioon $(r=-0,1)$. Analüüsist nähtub, et seotud on ka ingliskeelne töö- ja õpikeskkond ning segaperes eesti keelest loobumine, mis tähendab, et kes eelistab inglise keelt asjaajamises, ei poolda ka koduse keelena eesti keelt. Ingliskeelse hariduse kättesaadavuse soosimise ja perekeele vahel on nõrk negatiivne seos $(r=-0,12)$. Ingliskeelse hariduse üldise tähtsustamise ja segaperes eesti keele kasutamise soovi vahel on keskmine negatiivne korrelatsioon $(r=-0,33)$. Inglise keele kui töökeele ja eesti keele kui segaperekonna keele valiku vahel on nõrk negatiivne seos ( $\mathrm{r}=$ -0,19). Välisfirma Eesti esinduses eesti keelt eelistavad õpilased peaksid aga vajalikuks ka teisest rahvusest kaaslasega loodud peres eesti keelt kasutada. Niisiis järeldub sellekohasest nõrgast positiivsest seosest $(r=0,22)$, et omakeelse tööelu hindajad peavad lugu ka segaperekonna eestikeelsest suhtlusest. 
Vaadelda tasub sedagi, kuivõrd ollakse valmis keelehoiuks. Korrelatsioonianalüüs lubab väita, et nõrk positiivne seos $(r=0,22)$ valitseb vabatahtli$\mathrm{ku}$ keelehoiu ja keeleõppe mahu suurendamise vahel. Ilmselt annavad siin tooni õpilased, kes keelest kui niisugusest enam huvituvad. Vabatahtliku keeletöö suhtes soosivamalt meelestatud on valmis ka muulastega lähedasi suhteid looma. Seda ilmingut iseloomustab nõrk positiivne korrelatsioon $(\mathrm{r}=$ $0,12)$.

Tugev positiivne korrelatsioon $(\mathrm{r}=0,5)$ on etnilise avatuse ja muulastega lähedaste suhete loomise valmiduse vahel. Samuti tähtsustavad etniliselt avatud õpilased ingliskeelse hariduse kättesaadavust, kuid korrelatsioon on nõrk $(r=0,16)$.

\section{Klasteranalüüs}

Eelnevalt kirjeldasime sotsiodemograafiliste tegurite mõju erinevatele keelehoiakutele ning seda, kuidas on keelehoiakud omavahel seotud. Järgnevalt anname ülevaate, millised on Eesti koolinoorte tüüprühmad ehk kuidas uuringus osalenud õpilased hoiakute alusel grupeeruvad. Selleks on kasutatud k-keskmiste ${ }^{1}$ klasterdamise meetodit, mida tarvitatakse rühmitamisel sel juhul, kui osatakse klastrite arvu ennustada ning soovitakse saada klastriks rühmitamise aluseks olevate tunnuste kirjeldusi. Et uuringus kasutatud ankeedis on 44 küsimust, ei ole tüpoloogia loomisel mõttekas kasutada kõiki küsimusi, vaid nende põhjal moodustatud faktoreid. Klasterdamise aluseks on niisiis eespool kirjeldatud 11 faktorit (vt tabelit 2). Varasemas uuringus ilmnenud klastritega täiesti kattuvaid tüüpe ei ole. Sellegipoolest võib väita, et varasema ja hilisema uuringu andmete põhjal loodud klastrites on mõningaid sarnasusi: üldiselt eristuvad sarnaselt varasemale tugevalt eestimeelsed ja silmatorkavalt inglise keele meelsed noored ning etniliselt avatud ja suletud õpilased.

I klaster. Aktiivne inglise keele meelne noormees. Kasutab inglise keelt intensiivselt, mis lubab arvata, et ta valdab seda vähemalt heal tasemel. See omakorda võimaldab tal pragmaatilistel kaalutlustel eesti keelest inglise keele kasuks loobuda. Samuti tähtsustab ta ingliskeelset haridust ning pooldab selle riigipoolset finantseerimist. Pole niisiis imekspandav, et ka töökeelena aktsepteeriks ta eesti keele asemel inglise keelt. Ka välisfirma Eesti esinduses eelistab ta pigem inglise keelt. Tähtsustades ingliskeelset haridus- ja töökeskkonda, soovib ta keeleõppe mahu tõstmist ja seejuures ei pea ta niivõrd silmas eesti keele tundide arvu tõusu. Samal ajal on ta võrreldes teistesse klastritesse kuuluvate õpilastega kõige enam nõus tegelema vabatahtliku keelehoiuga, olles näiteks muulasest eakaaslasele eesti keele vestluspartneriks. Üldse iseloomustab teda etniline avatus ja suur valmisolek muulastega lähedasi suhteid luua. Seetõttu pole segaabielu tema puhul sugugi välistatud. Sellisel juhul eelistaks ta koduse keelena pigem eesti keelt. Üldiselt võib öelda, et tegemist on aktiivse noorega, kes küll väärtustab inglise keelt vahendina ja on avatud eluhoiakuga, kuid hindab siiski ka eesti keelt. Selles rühmas on $54 \%$ (27) neid, kes arvavad, et nende oma laste täisealiseks saamise ajal eesti keelel tööelus praktilist rolli kas kindlasti või pigem ei ole.

\footnotetext{
${ }^{1} \mathrm{k}$ tähistab klastrite arvu.
} 
Tabel 2.

Keelehoiakute tüpoloogia seitsme klastriga mudel*

\begin{tabular}{|l|c|c|c|c|c|c|c|}
\hline Klaster & I & \multicolumn{1}{|l|}{ II } & III & IV & V & VI & VII \\
\hline Klastri suurus & 50 & 123 & 132 & 123 & 105 & 78 & 121 \\
\hline Faktortunnuste keskmised \\
\hline $\begin{array}{l}\text { Inglise keele kasutamise } \\
\text { intensiivsus }\end{array}$ & 0,36 & $-0,81$ & 1,00 & $-0,52$ & $-0,31$ & 0,70 & $-0,32$ \\
\hline $\begin{array}{l}\text { Inglise keele kasutamine } \\
\text { pragmaatilistel kaalutustel }\end{array}$ & 0,61 & $-0,9$ & 0,84 & $-0,76$ & $-0,28$ & 0,84 & $-0,44$ \\
\hline $\begin{array}{l}\text { Inglise keel firma } \\
\text { töökeelena }\end{array}$ & 0,25 & $-0,16$ & 1,13 & $-0,53$ & 0,38 & $-0,20$ & $-0,92$ \\
\hline $\begin{array}{l}\text { Eesti keel välisfirma Eesti } \\
\text { esinduse töökeelena }\end{array}$ & $-0,08$ & 0,64 & 0,01 & 0,68 & $-0,47$ & 0,22 & $-0,77$ \\
\hline Vabatahtlik keelehoid & 0,84 & 0,43 & $-0,14$ & 0,01 & $-0,24$ & $-0,87$ & $-0,10$ \\
\hline $\begin{array}{l}\text { Ingliskeelse hariduse } \\
\text { kättesaadavus Eestis }\end{array}$ & 0,42 & 0,11 & 1,08 & $-1,11$ & $-0,25$ & 0,29 & $-0,49$ \\
\hline $\begin{array}{l}\text { Keeleõppe mahu } \\
\text { suurendamine }\end{array}$ & 0,75 & 0,32 & 0,22 & 0,07 & $-0,41$ & $-0,54$ & $-0,37$ \\
\hline $\begin{array}{l}\text { Ingliskeelse hariduse } \\
\text { tähtsus }\end{array}$ & 0,24 & $-0,13$ & 1,56 & $-0,95$ & $-0,04$ & $-0,08$ & $-0,42$ \\
\hline Etniline avatus & 0,26 & 0,6 & $-0,20$ & $-0,82$ & $-0,80$ & 0,44 & 0,58 \\
\hline $\begin{array}{l}\text { Muulastega lähedane } \\
\text { suhtlemine }\end{array}$ & 0,59 & 0,47 & $-0,18$ & $-0,66$ & $-0,93$ & 0,31 & 0,41 \\
\hline $\begin{array}{l}\text { Segaperekonnas eesti keele } \\
\text { kasutamine }\end{array}$ & 0,1 & 0,18 & $-0,97$ & 0,92 & $-0,43$ & $-0,14$ & 0,39 \\
\hline
\end{tabular}

* Faktortunnused on standardiseeritud tunnused, mis tähendab, et kogu valimi keskväärtuseks on 0 ning rühma positiivset keskväärtust tuleb tõlgendada keskmisest soosivama suhtumisena ning rühma negatiivset keskväärtust keskmisest vähem soosiva suhtumisena (Ehala, Niglas 2004: 2134).

Sellesse rühma kuulub tunduvalt enam noormehi kui neide. Klastrisse on koondunud peamiselt 10. klassi õpilased, klassi tüüpidest on esindatud peamiselt reaal- ja humanitaarklasside õpilased. Tugevalt on esindatud õpilased, kelle ühel vanemal on kõrgharidus. Maakondadest domineerib suure ülekaaluga Tartumaa. Klastrisse kuulub 6,8 \% (50) küsitluses osalenud õpilastest.

II klaster. Etniliselt avatud eestimeelne noor. Kasutab inglise keelt minimaalselt. Pole võimalik täpselt öelda, kas tema keelevaliku madal utilitaarsus on tingitud ta halvast inglise keele oskusest või soovist oma emakeelt säilitada. Viimane on siiski üsna tõenäoline, sest ta on keskmisest altim tegelema keelehoiuga. Kuigi ta pooldab ingliskeelset haridust ja arvab, et riik võiks sellesse oma panuse anda, ei pea ta seda oma laste jaoks oluliseks. Keeltest peab ta aga lugu ja soovib nende õppimise võimaluste suurendamist. Töökeeleks peab ta siiski tingimata eesti keelt. Seesuguse eesti keelele lojaalse 
hoiaku põhjal võiks arvata, et tegemist on etniliselt üsna suletud ja negatiivselt meelestatud inimesega. Kuid otse vastupidi: ta on teiste klastritega võrreldes muulaste suhtes kõige avatum, olles valmis nendega isiklikke lähedasi kontakte looma. Koduseks keeleks peaks aga, hoolimata suurest tolerantsusest teiste rahvuste suhtes, jääma eesti keel. Niisiis on tegu inimesega, kellel on väga tugev eesti identiteet, kuid kes on valmis lähedalt suhtlema ka teisest rahvusest inimestega. Selles rühmas on 18,1\% (22) neid, kes arvavad, et nende oma laste täisealiseks saamise ajal eesti keelel tööelus praktilist rolli kas kindlasti või pigem ei ole.

Noormeestel on selles rühmas väike ülekaal, tegemist on peamiselt 12 . klassi õpilastega. Klassi tüübiks on peamiselt tava- ja reaalklass. Enamasti on tegu õpilastega, kelle ühel vanemal on kõrgharidus. Elukohaks on valdavalt Harju-, Tartu-, Jõgeva- ja Raplamaa. Klastrisse kuulub 16,8 \% (123) küsitluses osalenud õpilastest.

III klaster. Inglise kultuurile orienteeritud noor. Kasutab inglise keelt võrreldes teiste klastrite õpilastega kõige enam ja oleks valmis loobuma eesti keele kasutamise võimalusest, kui see tähendab kokkuhoidu. Samuti eristub võrdluses teistesse klastritesse kuulujatega selgelt ingliskeelse hariduse pooldajana. Loomuliku jätkuna soosib ta märkimisväärselt tugevalt ka töökeskkonnas inglise keele kasutamist. Sellega seoses soovib ka keeleõppe mahu suurendamist. Eesti keelt ta tähtsaks ei pea, sest ei pea vajalikuks tegelda vabatahtliku keelehoiuga ega kasutada segaperes eesti keelt. Viimane tähendab võrreldes ülejäänud klastritega eriti negatiivset hoiakut. Üldse näib ta väärtustavat vaid ingliskeelset kultuuri- ja keeleruumi, sest kohalike muulastega suhtlemine on tema puhul välistatud. Selles rühmas on 46,9\% (61) neid, kes arvavad, et nende oma laste täisealiseks saamise ajal eesti keelel tööelus praktilist rolli kas kindlasti või pigem ei ole.

Klastris on veidi enam neide kui noormehi. Väikses ülekaalus on 12. klassi õpilased. Kõige enam on reaalklasside õpilasi. Kuigi eliitkooli õpilased üheski klastris ei domineeri, on kõige suurem hulk neist koondunud just sellesse klastrisse, samuti on selles klastris kõige enam (23\%) neid, kelle pere sissetulek on keskmisest kõrgem. Peres on kõrgharidus enamasti ühel vanemal. Regioonidest kerkib tugevalt esile Tartumaa, veidi vähem Harju- ja Jõgevamaa. Klastrisse kuulub 18 \% (132) küsitluses osalenud õpilastest.

IV klaster. Eestimeelne etniliselt suletud neiu. Kasutab inglise keelt vähe ega otsusta selle kasuks ka kokkuhoiu eesmärgil. Ingliskeelset haridust ta ei tähtsusta ning on tugevalt vastu selle kättesaadavuse laiendamisele. Nii ei poolda ta ka töökeelena inglise keelt, nähes teiste klastritega võrreldes kõige kindlamalt ka välisfirma Eesti esinduse töökeelena eesti keelt. Etniliselt on ta väga suletud, soovides suhelda vaid omakeelsete kaasmaalastega. Seega on ta muulaste suhtes kinnine ning püüab kontaktolukordi vältida. Kirjeldatud vältiv hoiak muudab üsna ebatõenäoliseks võimaluse, et tema tulevane abikaasa või elukaaslane on muust rahvusest. Kui ta aga peaks kunagi kuuluma segaperekonda, siis on suhtluskeeleks kindlasti eesti keel. Tegemist näib olevat üsna kinnise loomuga eestimeelse inimesega. Selles rühmas on $18,8 \%$ (23) neid, kes arvavad, et nende oma laste täisealiseks saamise ajal eesti keelel tööelus praktilist rolli kas kindlasti või pigem ei ole. 
Klastris on tunduvalt rohkem tütarlapsi ja 12. klassi õpilasi. Iseloomulik on tava- ja reaalklassi õpilaste arvuline ülekaal. Kui teistes klastrites on ülekaalus linnanoored, siis sellesse rühma on koondunud kõige suurem hulk maakoolide õpilasi, protsentuaalselt on neid kõikide maakoolide õpilaste arvust $21,6 \%$. Nagu ülejäänud klastrites on ka siin enamik õpilasi keskmise sissetulekuga peredest. Sellegipoolest on sellesse rühma koondunud võrreldes teistega kõige suurem hulk keskmisest madalama sissetulekuga vanemate lapsi. Protsentuaalselt moodustab nende arv 25,7 \% kõigist keskmisest kehvemal järjel õpilastest. Kirjeldatud hoiakuga õpilaste vanemad on suurelt osalt kesk(eri)haridusega. Maakondade lõikes on klastris enim Harju-, Tartuja Võrumaa noori. Klastrisse kuulub 16,8 \% (123) küsitluses osalenud õpilastest.

V klaster. Töökeelena inglise keelt hindav neiu. Kasutab inglise keelt vähe ega loobu kokkuhoiu eesmärgil eesti keelest. Et ta ingliskeelset haridust ei väärtusta, ei näe ta ka põhjust selle riigipoolseks finantseerimiseks. Siiski pole tegu ka eesti keele patrioodiga, sest keelehoiuga ta ei tegeleks ega töökeelena eesti keelt ei kasutaks. Seesugune vastuolu inglise keele kui hariduskeele väärtustamatuse ja inglise keele kui töökeele hindamise vahel tekitab küsimusi. Tegu võib olla noorega, kes on kuulnud, et inglise keel on justkui sotsiaalse heaolu ja majandusliku kindlustatuse tagatis. Sellest hoolimata puudub tal endal motivatsioon seda õppida ning oma lastele võimaldada. Kui tema tulevane abikaasa või elukaaslane poleks rahvuselt eestlane, siis ei teeks ta lisapingutusi, et oma emakeelt lastele edasi anda. Etniliselt ta aga avatud pole ning torkab silma tugeva negatiivse hoiakuga muulastega suhtlemise osas. Selles rühmas on 33,7 \% (35) neid, kes arvavad, et nende oma laste täisealiseks saamise ajal eesti keelel tööelus praktilist rolli kas kindlasti või pigem ei ole.

Sooliselt domineerivad selles rühmas tugevalt tütarlapsed, vähesel määral 10. klassi õpilased. Klassi tüüp on enamasti tavaklass. Õpilaste vanemad on selles klastris suuresti kesk(eri)haridusega. Suurima piirkondliku esindatusega paistavad silma Tartu-, Rapla-, Põlva- ja Harjumaa. Klastrisse kuulub 14,3\% (105) küsitluses osalenud õpilastest.

VI klaster. Keelevalikul olukorrast lähtuv noor. Kasutab inglise keelt aktiivselt ja on keeleküsimustes väga praktiline, see tähendab, et on materiaalsetel kaalutlustel valmis inglise keele kasuks otsustama. Kuigi ta ei tähtsusta eriti ingliskeelset haridust, pooldab ta selle omandamise võimaluste avardamist. Töökeelena näeb ta eesti keelt, seda ka välisfirma Eesti esinduses. Tugevalt on ta vastu nii keeleõppe mahu suurendamisele kui ka vabatahtlikule keelehoiule. Segaperes ei näeks ta vaeva oma teisest rahvusest pereliikmetele eesti keele õpetamisega. Muulaste suhtes on ta aga avatud ning suhtlemisaldis. Selles rühmas on 17,9 \% (14) neid, kes arvavad, et nende oma laste täisealiseks saamise ajal eesti keelel tööelus praktilist rolli kas kindlasti või pigem ei ole.

Väikese ülekaaluga kuuluvad sellesse rühma noormehed, klasside lõikes on veidi enam 10. klassi õpilasi. Eriti domineerivad tava- ja reaalklasside noored. Väga vähe on selles klastris nende vanemate lapsi, kellest mõlemal on kõrgharidus. Maakondadest on esindatuimad Tartu-, Harju- ja Põlvamaa. Klastrisse kuulub 10,7 \% (78) küsitluses osalenud õpilastest. 
VII klaster. Eestimeelne neiu. Kasutab inglise keelt vähe ega loobu utilitarismist lähtudes eesti keelest. Ingliskeelset haridust ei väärtusta ega näe põhjust, miks riik sellesse panustama peaks. Kõikide eelmiste klastritega võrreldes avaldab ta tugevaimat vastuseisu nii ingliskeelsele töökeskkonnale kui ka eesti keele kasutamisele välisfirma Eesti esinduses. Seega arvab ta, et eestlane ise peab oma keelele kindlaks jääma, kuid ei pea tingimata vajalikuks võõrast päritolu firmade ja inimeste keelelist integreerimist. Lisapingutusi nõudvate keelealaste tegevustega ta pigem kokku ei puutuks, nii on tema puhul välistatud vabatahtlik keelehoid ja keeletundide arvu suurendamine. Samal ajal on tegemist etniliselt avatud noorega, kes teisest rahvusest inimesega pere luues jääks kindlaks eesti keelele. Selles rühmas on 32,5 \% (39) neid, kes arvavad, et nende oma laste täisealiseks saamise ajal eesti keelel tööelus praktilist rolli kas kindlasti või pigem ei ole.

Neide on selles klastris rohkem kui noormehi, veidi enam on 10. klassi õpilasi. Õppesuundadest on esiplaanil tava- ja reaalklassid. Vähe on selles klastris neid, kelle mõlemal vanemal on kõrgharidus. Siia kuuluvad Harju-, Tartu- ja Raplamaa õpilased, kokku 16,5 \% (121) küsitluses osalenud õpilastest.

\section{Järeldused ja kokkuvõte}

Uuringust ilmneb, et inglise keelt tarvitatakse sageli ning võrdlus varasema uuringuga lubab väita, et selle kasutamise aktiivsus on tõusuteel. Nende hulk, kes kasutavad inglise keelt harva või ei kasuta mitte kunagi, moodustasid kaheksa aastat tagasi oma põlvkonnast enamuse (54\%). Praeguses 16-18-aastaste põlvkonnas on nende hulk $11 \%$ madalam ja nad on muutunud vähemuseks. Umbes sama palju on suurenenud nende hulk, kes oleksid valmis loobuma eesti keelest mõnes kitsas nišis, kui see muudaks tarbimise odavamaks. Nad moodustavad $63 \%$ vastanutest, mis on rohkem kui neid, kes kasutavad inglise keelt mõnikord või sagedamini. See tähendab, et olmes on inglise keele episoodiline eelistamine piiratud peaasjalikult keeleoskusega ja et ka need, kes inglise keelt veel eriti ei kasutagi, väljendavad valmisolekut seda käitumist muuta. Seos inglise keele kasutamise intensiivsuse ja valmisoleku vahel seda eelistada, kui see annaks mingi materiaalse säästu, on keskmise tugevusega $(r=0,44)$.

Kõneka faktina on ingliskeelse hariduse võimalikkuse pooldajaid endiselt suur enamus: $72 \%$. Positiivse nihkena on $8 \%$ võrra vähenenud nende hulk, kes peavad ingliskeelse hariduse kättesaadavust kindlasti vajalikuks. Hea märk on ka see, et isikliku elu valikutes on inglise hariduskeele eelistajaid oluliselt vähem (41\%) ja toimunud on isegi väike, kolmeprotsendiline langus, kuid see võib olla ka ebaoluline kõikumine. Jätkuvalt on eesti keel kõrgelt väärtustatud segaperekonnas, juhul kui tulevane abikaasa ei ole eestlane: oluliseks peab eesti keelt perekonnas endiselt üle $80 \%$, samal ajal on $8 \%$ vähenenud nende hulk, kes kindlalt nii arvavad. Võib-olla on siin tegemist ohtliku suundumusega, aga võib-olla ei ole see põlvkond oma hoiakutes lihtsalt nii kategooriline.

Ülaltoodust võib järeldada, et õpilaste keelehoiakute üldmall on jäänud samaks kui üheksa aastat tagasi: identiteedi jaoks ebaolulistes kasutusvaldkondades ollakse pragmaatilised ja valmis eelistama seda keelt, mis võimaldab kulusid kokku hoida. Identiteedile olulistes valdkondades aga eelistatak- 
se valdavalt eesti keelt. Samal ajal näitab ingliskeelse hariduskeele tähtsustamise ja segaperekonnas eesti keele eelistamise suhteliselt kõrge negatiivne korrelatsioon ( $r=-0,33)$, et instrumentaalsete ja integratiivsete keelehoiakute vahel on arvestatav seos. Kuigi isiklikku valikut puudutavates küsimustes ollakse ülekaalukalt eestimeelsed, väljendatakse üldisemas ühiskondlikus plaanis toetust inglise keelele. Seetõttu võib arvata, et ingliskeelse suhtluse, haridus- ja tööelu jätkuv ja laienev normiks pidamine ja tegelikkuseks muutumine hakkab ilmselt vähehaaval negatiivselt mõjutama võimalikke isiklikke valikuid ka nendes keelevaldkondades, mis on otseselt seotud identiteedi kujunemise ja edasikandmisega.

Kui vaadata sotsiodemograafiliste tunnuste ja keelehoiakute seotust, siis on kõige silmatorkavam klasteranalüüsist ilmnev tugev seos segaperekonnas eesti keelest loobumise ning eliitkoolis õppimise ja vanemate jõukuse vahel. Eesti keelt vähe väärtustavate klastrisse kuulub $18 \%$ valimist ning ligi pool nendest arvab, et oma laste täisealiseks saamisel ei ole eesti keelel enam tööelus praktilist väärtust. See annab tunnistust, et edasipüüdlikum ja ettevõtlikum eestlaskond on eesti identiteedi suhtes suhteliselt küüniline. Kasutatakse küll selle ühiskonna loodud hüvesid, kuid meil väga levinud ideoloogia kohaselt, et igaühe heaolu sõltub tema enda ettevõtlikkusest, ollakse valmis seda hülgama, kui see muutub karjäärile segavaks. Meil on kombeks rääkida vene noorte ebalojaalsusest Eestile, kuid ka etniliste eestlaste hulgas on märkimisväärne osa neid, kes hoolimata sellest, et kõnelevad eesti keelt emakeelena, pole põrmugi lojaalsemad.

See tõstatab küsimuse, kas on võimalik midagi teha keelehoiakute muutmiseks. Kindlasti on koolides võimalik intensiivsem patriootlik kasvatustöö, kuid on vähetõenäoline, et haridussüsteem suudab ümber kujundada elus iga hinna eest läbilöömisele orienteeritud perekondadest pärit noorte väärtussüsteemi. Pealegi on Eestis olemas juba üsna toimiv laulu- ja tantsupidude traditsioonil põhinev identiteedikasvatussüsteem, millele oleme ilmselt tänu võlgu selle eest, et hoolimata inglise keele kasutamise intensiivsuse tõusust ei ole toimunud märgatavat keelehoiakute halvenemist. Identiteedikasvatuse jätkuv intensiivistamine võib tekitada küllastatuse, mis tõenäoliselt annaks soovitule vastupidise efekti. See ei tähenda muidugi, et ei tuleks keelehoiakute kujundamisega tegelda, kuid tegevuse fookus peaks olema suunatud pigem sellele, et luua olukord, kus olmeolukordades ei oleks põhjust eelistada inglise keelt eesti keelele ka episoodiliselt. Sest pole kahtlust, et kui inimestel on millegi tõttu kasulik tarvitada inglise keelt eesti keele asemel ja kui ta inglise keelt piisavalt oskab, siis ta seda ka tarvitab. Iga selline olukord muudab inglise keele loomulikumaks ja vähendab eesti keele kasutamist, mille tulemusel hakkavad muutuma ka hoiakud eesti keele kui eesti identiteedi kandja suhtes. Eliitkoolide õpilaste leigus eesti identiteedi suhtes võib osalt olla tingitud ka inglise keele suurest osatähtsusest neis koolides.

Rääkides eesti keele jätkusuutlikkusest, tuleb vaadelda ka seda, millist mõju sellele avaldavad hoiakud Eesti venelaste suhtes. Võrreldes 2003. aastaga on kasvanud nende hulk, kes on valmis pidama kohalikku vene elanikkonda eesti ühiskonna osaks ja kes peab oluliseks eesti ja vene kogukonna jätkuvat lõimumist: 2011. aastal toetas seda $76 \%$ vastanuist, 2003. aastal $71 \%$. Samal ajal on kahanenud nende hulk, kes sooviksid ise kindlasti luua tihedamaid kontakte mitte-eestlastega: 2003. aastal oli neid $55 \%$ vastanuist, 
kordusuuringus $41 \%$. See näitab, et venelasi aktsepteeritakse Eesti elanikena, osana Eesti riigist, kuid on muututud ettevaatlikumaks isiklike kontaktide loomisel. Osalt võib see tuleneda pronkssõdurikriisist, kuid siin võib avalduda ka eesti keelekogukonnale omane korporatiivne käitumismuster: teise keele ja kultuuri ühtlustavale mõjule avaldatakse järjekindlat vastupanu (Ehala 1998: 734). Me justkui kardaksime, et muulased rikuvad meie keele ära. Ehk just seetõttu väldime nendega lähedaste suhete loomist. Ja kuigi me kohati sulandame inglise keelt ja kultuuri eesti omaga, näitab ingliskeelse hariduse ja töökeele pooldamine kalduvust ise sulanduda. Niisiis muretsetakse jätkuvalt eesti keele elujõulisuse pärast ega kasutata ära võimalust muust rahvusest inimeste lõimimise abil eesti keele kõnelejate arvu suurendada (Ehala 1998: 737). Avatus luua lähikontakte vene kodukeelega noortega koos eesti keele väärtustamisega segaperekonnas võib anda vägagi tugeva lõiminguefekti, kui ühiskond laiemalt oleks sellise arengustsenaariumi suhtes positiivselt meelestatud.

Kokkuvõttes võib öelda, et eesti õpilaste keelehoiakud on viimase üheksa aasta jooksul olnud suhteliselt stabiilsed, kuid oluliselt on kasvanud inglise keele kasutamise intensiivsus. See tundub olevat ka eesti keele jätkusuutlikkuse võtmevaldkond: tuleb tagada eesti keele loomulik kasutamine neutraalsetes igapäevaolukordades, mis on eelduseks selle väärtustamisele identiteedimarkerina. Vajaduse korral tuleks luua olukord, kus eesti või inglise keele vahel valiku tegemisel oleks loodud eelis eesti keelele, näiteks makstaks eestikeelsetel õppekavadel õppijatele stipendiumi, laiatarbetarkvara eestikeelsed versioonid oleksid odavamad kui ingliskeelsed jms. Identiteedikasvatuses tuleks hoiduda liigsest rahvuskesksusest ja igati soodustada kontakte kohalike vene taustaga noortega, pikas perspektiivis võiks see viia Eesti kahe põhirahva tiheda lõiminguni, mis omakorda aitaks kasvatada eesti keele kõnelejaskonda keskpikas perspektiivis.

\section{Kirjandus}

De B ot, Kees, St o e s s e 1, Saskia 2002. Introduction: Language Change and Social Networks. - International Journal of the Sociology of Language, nr 153, lk $1-7$.

Eh a la, Martin 1998. Eesti keele arenguteid: korporatiivsus versus avatus. Keel ja Kirjandus, nr 11, lk 733-739.

E h a l a, Martin, Nigl a s, Katrin 2004. Eesti koolinoorte keelehoiakud. - Akadeemia, nr 10, lk 2115-2142.

F r e n c h, Sabine Elizabeth, S e i d m a n, Edward, A 1 l e n, LaRue, A b e r, J. Lawrence 2006. The Development of Ethnic Identity During Adolescence. - Developmental Psychology, nr 42, lk 1-10.

G a r r e t t, Peter 2010. Attitudes to Language. Cambridge: Cambridge University Press.

Garrett, Peter, C oupland, Nikolas, Willi a m s, Angie 2003. Investigating Language Attitudes. Social Meanings of Dialect, Ethnicity, and Performance. Cardiff: University of Wales Press.

Greenwald, Anthony G., Banaji, Mahzarin R., Rudman, Laurie A., F a r n h a m, Shelly D., No s e k, Brian A., Mell ott, Deborah S. 2002. A Uni- 
fied Theory of Implicit Attitudes, Stereotypes, Self-Esteem, and Self-Concept. Psychological Review, nr 109, lk 3-25.

Krosnick, Jon A., Judd, Charles M., Wittenbrink, Bernd 2005. The Measurement of Attitudes. - The Handbook of Attitudes. Ed. Dolores Albarracin, Blair T. Johnson, Mark P. Zanna. New Jersey: Lawrence Erlbaum Associates, lk 21-79.

L a m bert, Wallace E., Hodg s on, R. C., Gardner, Robert C., Fillen b a u m, Samuel 1960. Evaluational Reactions to Spoken Language. - Journal of Abnormal and Social Psychology, nr 60, lk 44-51.

P h in ne y, Jean S. 1990. Ethnic Identity in Adolescents and Adults. Review of Research. - Psychological Bulletin, nr 108, lk 499-514.

\section{Language Attitudes of Estonian School Students in 2011}

Keywords: language attitudes, Estonian language, Estonian students, education, identity, language maintenance

Eight years ago, in 2003 Martin Ehala and Katrin Niglas conducted a representative study among Estonian school students. The aim was to get an overview of the attitudes that could influence young people's language preferences in situ-ations or environments where their choice is between Estonian and English, such as Internet communications, entertainment, school and university, in the workplace and with family. The results showed that in the eyes of the students Estonian has quite a strong integrative value which cannot be said about the instrumental value. A similar survey conducted in 2011 shows that language attitudes of students have generally remained the same as they were eight years ago. However, it is clear that the use of English is increasing and to ensure the sustainability of the Estonian language its natural use of in everyday life should be guaranteed. This would be the precondition of its valuation as a marker of identity.

Anni Tammemägi (b. 1987), MA, Teacher of Estonian Language and Literature, anni_tammemagi@hotmail.com

Martin Ehala (b. 1963), PhD, University of Tartu, Professor of Mother Tongue Teaching, Senior Researcher, ehalam@ut.ee 